\title{
THE APPEAL TO REASON AND THE \\ FAILURE OF THE SOCIALIST \\ PARTY IN 1912*
}

\author{
Robert Tuttle \\ University of Kansas
}

Mid-American Review of Sociology, 1983, Vol. VIII, No. 1:51-81

One of the classic problems studied by social scientists is why there is no socialism in the United States. The Socialist Party has not been a significant political force since the early twentieth century. A content analysis of the Appeal to Reason, the most popular Socialist newspaper of this era, reveals weaknesses in the Socialist Party's methods for inaugurating socialism. The Socialist Party did not offer a distinct alternative to the major parties because it moderated its demands in order to appeal to middle class voters. The major parties absorbed these liberal policies and the Socialist Party lost its strength.

\section{INTRODUCTION}

If Socialism follows as a necessary reaction of capitalism, the country with the most advanced capitalist development, namely the United States, would at the same time be the one providing the classic case of Socialism (Sombart, 1976:15).

This statement has not proven to be any truer now than when Sombart first presented it in 1906. The failure of the development of socialism in the United States has intrigued

*This is an edited version of an undergraduate honors thesis at the University of Kansas. I wish to thank Robert J. Antonio who supervised the writing of this paper. I also wish to thank Alan Sica for help in formulating the concept for the paper. I appreciate the insightful comments of David Willer and the assistance of Scott McNall. 
many social scientists. ${ }^{1}$ This problem is particularly perplexing in that many other countries do have strong Socialist movements. It is widely believed that the Socialist Party was never a political factor in America, but in the early part of the twentieth century it was rapidly gaining strength. At its height it had over one-hundred and fifty thousand dues paying members, published hundreds of newspapers, elected more than onethousand of its members to political office, and secured passage of a considerable body of legislation (Kipnis, 1952:5). However, just when it appeared the Socialist Party would establish itself politically, it rapidly declined in strength.

The Appeal to Reason was the most influential radical newspaper of its day. It did much to set the tone of the American Socialist movement (Kipnis, 1952:46). The Appeal was the leading outlet for the right-wing of the Socialist Party, which felt that socialism would be introduced gradually through the existing machinery of the state, rather than through a proletarian revolution. The right-wing was in control of the Socialist Party for the most part, and the programs for building socialism advocated by the Appeal can be viewed as representative of the Socialist Party's philosophy. Therefore, it is possible to investigate reasons for the failure of the Socialist Party through an examination of the Appeal. ${ }^{2}$

This study begins with a brief history of the Appeal to Reason, along with a discussion of the ideological factionalism within the Socialist Party which enables one to understand the editorial position of the Appeal. For the most part, this paper concerns the Appeal's coverage of the 1912 presidential election campaign, with an emphasis on the political strategy of the Socialist Party and its relation to the Party's demise.

The content analysis of the Appeal to Reason is an attempt to discover weaknesses within the Socialist movement that eventually led to its downfall. The study focuses primarily on the Appeal's Propaganda methods and strategy to win adherents for the Socialist cause. Contradictions and weaknesses in the strategy are brought to light that are possible contributing factors to the decline and eventual failure of the Socialist Party to become a mass party in the United States.
American socialism arose in the wake of the failure of Populism. Some continuities existed between Populism and socialism in the early 1900 s, especially in the Southwest, but these should not be exaggerated. ${ }^{3}$ The Socialist Party built a new and different constituency than the Populist Party. Green (1978:27) states: "the disappearence of so many Populist voters created a somewhat new radical constituency for the southwestern Socialist." Radicalism was becoming more prominent in coal mining districts and labor was becoming involved with socialism. Although the constituencies of the Populist Party and the Socialist Party were somewhat different, Populist ideas remained very much alive. The immediate demands of the Socialists and the Progressives were rooted in the Populist tradition. The final remnants of the Populist Party were gone, but many of their ideas remained.

\section{Appeal to Reason}

The most popular newspaper which expressed the ideas of the radical tradition was the Appeal to Reason. Founded in Kansas City, Missouri, in 1895 by Julius Wayland, ${ }^{4}$ the Populist campaign of 1896 almost killed the Appeal, but Wayland was able to make a new start in Girard, Kansas, a small farming and mining community of $3,500 . .^{5}$ Through vigorous circulation drives the Appeal exceeded 100,000 in publications by 1899 . In 1904, Wayland leased the Appeal to Fred Warren who took over the burden of running the paper while Wayland concentrated on turning out propaganda for it. In 1905, Eugene Debs began writing for the Appeal; his popularity caused circulation to rise sharply and Debs was made an associate editor of the Appeal, a position he held from 1907 until 1912 (Cooley, 1973: 5-11).

As the most influential radical newspaper of its day, the Appeal at its height had a circulation of roughly 300,000 to 500,000 (Kipnis, 1952:248). Socialist historian Ira Kipnis calls the Appeal "the trail-blazer of the socialist movement throughout the nation," which "did much to set the tone of the American socialist movement" (1952:46). The Appeal was successful because of its style. Its socialism combined the frontier 
militancy of the old Populist movement, the revolutionary class consciousness of the laboring class, and the utopianism offered by Edward Bellamy. The Appeal excelled at sensationalism and did not worry about being moderate in its language. ${ }^{6}$

The fiercely loyal "Appeal Army" was the backbone of the Appeal's success. Its 60,000 members traveled throughout the country shouting the praises of socialism and selling subscriptions. ${ }^{7}$ One member was credited with selling over 100,000 subscriptions (Green, 1978:128-129). When the Appeal faced a financial crisis, it was members of the "Appeal Army" who contributed whatever they could to save it. It is hard to say how many converts the Appeal actually gained. A national survey in 1908 showed that just 52 percent of the Socialist Party rank and file were converted by reading Socialist literature. But Socialist literature played a very important role in the conversions of the agitators of the "Appeal Army" ( $74 \%$ converted by reading); who in turn converted many others in their travels around the country (Green, 1978:128-133).

\section{Ideological Factionalism}

In order to understand the editorial positions of the Appeal to Reason it is necessary to examine the ideological factionalism within the Socialist Party that had existed almost since its formation. Each faction of the Socialist Party differed on how they thought socialism should be brought about in the United States.

The more militant, or left-wing, of the Socialist Party adhered to the more traditional Marxist line. The left-wing theory which guided the Socialist Party for the first four or five years of its existence (1901-1906) looked upon socialism as another step in the revolutionary movements caused by changing economic conditions. Socialism was the next natural step of society's political and economic development (Kipnis, 1952:108-110).

According to the left-wing, the main function of the Socialist Party was to heighten class consciousness. They accepted the Marxist notions of the proletariat (or the wage worker) and the capitalist (industrial owners and the owners of the great trusts and monopolies). The proletariat was engaged in a constant struggle against the capitalists, and once individual members of the proletariat realized that their battle for higher wages and better working conditions was a part of the general class struggle, they would become class conscious. The proletariat would then join the Socialist Party in order to do battle with the other major parties (Kipnis, 1952:110-111).

Economic organization of the working class was the main goal of the left-wing. Electing a small number of Socialists to office would not transform the capitalist system because industry would still be controlled by the capitalist. But the Left was not against all political activity. The election of Socialists had some value because Socialist officials could help prevent the state (e.g., the police and the courts) from being used against the workers (Cooley, 1973:12). The true Socialist state could only come about after the proletariat had seized total control of the machinery of government and the means of production (Kipnis, 1952:111). The left-wing favored industrial unionism, or one large union that would include all workers of an industry, rather than the craft union concept favored by the American Federation of Labor. These industrial unions would be affiliated with unions of other industries to form a giant confederation of unions. The eventual goal of the left-wing was a general strike during which they would seize power from the capitalist (Cooley, 1973:12).

The ideology of the right-wing of the Socialist Party was based almost solely on the teachings of the Marxist revisionist Edward Bernstein. Rejecting the position of the Left that socialism would win a clear cut victory, they argued that socialism would be introduced gradually through the existing machinery of the state. Legislation favoring the working class such as the Sherman Anti-Trust Act and minimum wage laws were steps towards socialism, and such reform would continue until eventually "a step at a time" America became a Socialist society (Cooley, 1973:13).

The right-wing felt that socialism was not a class movement, but a movement involving the whole human race. In fact, many right-wingers developed a hatred for the working class, 
calling the masses of mankind "stupid indolent philistines." Socialism would benefit all classes and social progress must be led by learned men of all classes. The ballot was the means for inaugurating true socialism, not force and bloodshed. In order to win votes, the Socialist Party had to appeal to all classes, not just the working class. In attempting to appeal to the middle class, the right-wing moved further away from the left-wing's revolutionary activity (Cooley, 1973:13-14; Kipnis, 1952:121).

Originally, the center of the Socialist Party was almost indistinguishable from the Left. The left-wing worried about the class makeup of the party. It recognized the growing influence of the middle class in the proletarian party, and felt that members of the middle class were unreliable and were really only reformers. The Left thought the greatest danger facing the party was the influence of the middle class in the working class movement. The center was more willing to accept the middle class, especially middle class votes. It was more concerned with electoral growth at the polls and pulled away from the left-wing when they felt its revolutionary activities interfered with electoral growth (Kipnis, 1952:116-117). This separation started in 1905, after the left-wing formed the Industrial Workers of the World (IWW), an attempt to establish an industrial union. But the IWW soon became associated with violence and sabotage in the public mind, and the center feared that it would alienate middle class voters. After the 1908 elections, the center separated completely from the left and joined the right-wing. By the election of 1912, the center-right coalition controlled the Socialist Party (Kipnis, 1952:214-242).

Although the Appeal to Reason attempted to avoid intraparty disputes, ${ }^{8}$ its propaganda was for the most part right-wing. It reflected the philosophy of its founder, Julius Wayland, who was convinced that "the way to socialism in America was through the book and the ballot, and not through general strikes and revolutionary activity." $\mathrm{He}$ was convinced that American working men, once the nature of capitalism and class struggle were explained to them, would "proceed peaceably to the voting booth and inaugurate socialism" (Cooley, 1973: 8). Wayland believed his task was to "educate workers in the fundamentals of Socialist doctrine, by disseminating Socialist propaganda as quickly and as broadly as possible" (Cooley, 1973:8). This meant a constant hammering of Socialist thought in every issue of the Appeal. This statement is typical:

Socialism proposes three things: First, social ownership of all the means of production and distribution that are socially used. Secondly, democratic control of the socially owned property, together with an extension of the principle of democracy in politics. Third, until the above can be realized, and as a means toward securing them, all lawful and peaceable measures that will cripple the present capitalist profit system and improve the conditions and power of the working class (Jan. 27, 1912:1).

The Appeal subscribed to the right-wing theory that some forms of socialism already existed in America. One article points out that public schools, highways, and the postal service were examples of socialism (Oct. 26, 1912:4). It also called for the use of the ballot to inaugurate socialism:

For the first time in all history you who toil possess the power to peacefully better your own condition. The little slip of paper which you hold in your hand on election day is more potent than all the armies of the earth. To that ballot the despots must bow; before its alchemy the mythical power of money melts away and is as the fleeting mists before the morning sun (Aug. 31, 1912:1).

However, with Eugene Debs as an associate editor, the Appeal did move to the left on occasion. Debs was a member of the left-wing, and because of his influence, the Appeal took a more sympathetic view of workers who tried to win concessions by striking (Cooley, 1973:18). By 1912 right-wingers had taken to criticizing strikers in order to appeal more to the middle class, but an article discussing a strike at Lawrence, Massachusetts, in 1912 states: 
The strike at Lawrence is immeasurably more than a strike. It bears all the indications of class warfare. ... Every such strike as that at Lawrence teaches lessons of great value and ought to be productive of good results.... Whatever of power has been asserted in behalf of the workers at Lawrence has been due solely to organization without which workers are always helpless.... The power of industrial organization, the unity of all the workers regardless of their particular trade or occupation .. has certainly made itself felt in the Lawrence strike (March $16,1912: 4)$

But usually the Appeal followed the right-wing ideology in an attempt to compete with the major parties for middle class votes. To understand the problems this caused for the Appeal and right-wing ideology in general, we must examine the political climate of the times.

\section{The Progressive Era}

The flow of protest unleashed by Populism reached its peak in 1912. There was a legitimate Socialist movement at the time, the main issue of the major parties was reform of the economic system, and radicalism was more popular than ever in American politics. ${ }^{9}$ However, this rise of insurgency held as much threat to the Socialist movement as it did promise. Socialists had made some electoral progress, particularly on the local front, ${ }^{10}$ but Socialists had been gaining ground because the reform characteristics of the party appealed to the middle class, and the new reform movements within the major parties represented a threat to this appeal. ${ }^{11}$

The activists in this reform movement, the Progressives, felt they could solve the problems of American society without drastic changes. They stood for a program which would combat the dangers from the extreme left and right. Their first line of action was to reform business by restoring competition. The second was to minimize the brutal exploitation of the working class by assuring minimal standards of social decency. The national government could accomplish both of these goals. Mazmanian (1974:56) writes:
The growing polarization along class lines won for the Reformist cause the support of the electorate. Offering an alternative to class conflict, reformers proposed that government act as an unprejudiced arbiter between competing interests. The state would be neutral, it would be administered by experts and would regulate the economy for the benefit of all.

The reformists did not define the problems of American society in terms of class. The problem was in the hearts of all men and could be controlled only through an adjustment of the institutions of government so that no group got too much power. The problems in American society could not be corrected by the victory of one class over another (Cooley, 1973: 23). Although radical in appearance, the Progressives had no intention of letting socialism spread through America. ${ }^{12}$

The attempt to inaugurate socialism through the ballot brought the party into direct conflict with the Progressives. Realizing the competition for middle-class votes, the Appeal vehemently attacked the Progressives. Right-wing Socialist theory called for the enactment of social reforms improving the conditions of the working and middle classes under capitalism, moving gradually towards socialism. The party was to obtain these reforms through the election of Socialist officials. When these officials became numerous enough, they would pass reform legislation themselves; meanwhile, the growing Socialist vote would frighten elected representatives of the two major parties into adopting some social legislation (Kipnis, 1952: 243). An article in the Appeal argued:

Do you not see that every vote they (old parties) lose to the Socialists will scare them into doing something for you? Without your vote they could not rule, and rather than lose your vote they will make some laws in your interest - but do you expect them to do this while they get all your votes? If you have any horse sense you will give them a scare by increasing the Socialist vote, even if you do not believe in the whole program of Socialism (April 27, 1912:4). 
As the 1912 election year approached the Appeal was confident. Membership in the Socialist Party had since 1908 increased from 50,000 to 118,000 members, which would mean a vote of close to two million if the same ratio of voters to dues paying members held (Cooley, 1973:28). But neither the Socialist Party nor the Appeal realized at that time how strong the Progressive forces within the major parties had become. Rather than facing old-line politicians in the presidential race, the Socialists confronted two seemingly reform minded candidates, Woodrow Wilson and Theodore Roosevelt.

\section{The Appeal Attacks the Candidates}

When Woodrow Wilson defeated Champ Clark for the Democratic nomination for President, it was a severe blow to the Socialist Party. Clark was a shrewd, old style politician and the Appeal would not have had difficulty criticizing him effectively. Wilson had established an admirable record as a reform governor of New Jersey, and had displayed independence from the Democratic machine that had helped him win the governor's seat (Cooley, 1973:24). Most importantly, Wilson was a classic Progressive. ${ }^{13}$

Wilson was attempting to recapture the past when the "American Dream" was perceived as a reality. He realized a great part of the American public considered an attack on business monopolies essential to political freedom. ${ }^{14}$ Wilson was the candiate who would save the common people from the great powers of the corporations. The Socialists thought this would be their issue and they realized the reform candidates were stealing their thunder.

The Appeal struggled to criticize Wilson effectively. $\mathrm{He}$ could not be labeled as a tool of the bosses because he showed independence from the political machines. In its Democratic edition (Aug. 3, 1912), the Appeal offered its entire front page to Wilson to state why he should be elected. His refusal of the offer was used by the Appeal to demonstrate that he was the enemy of the working class.

Doc Wilson has had nothing to do with the working class through all his days. The Appeal humbly apologized to the 'aristocratic iceburg' for daring to give him an opportunity to speak to the working class. It was only expected that he would ignore such a request.... What has he to do with the working class? What has he ever had to do with it? (Aug. 3, 1912:1). ${ }^{15}$

Wilson was also criticized for being an opponent of organ ized labor, but the Appeal was forced to discuss events of Wilson's life before he even became a candidate for public office saying, "Wilson was a close personal friend to President Cleveland and was in hearty accord with him when he sent federal troops to Chicago to crush the railroad unions and force the strikers back to work" (Aug. 3, 1912:1). The Appeal never produced any record other than this obscure reference to prove Wilson was against organized labor.

Rather than criticizing Wilson for being a "tool of the bosses," the Appeal criticized him for being disloyal. After having been helped to the governorship by the New Jersey political machine, Wilson dumped them. The Appeal said that a man who did not remember his old friends should not be elected as President (Feb. 3, 1912:4). According to the Appeal, Wilson's every move was misguided.

The Appeal never could find an effective strategy for critizing Wilson. Portraying him as a nominee of Wall Street was incorrect. ${ }^{16}$ It was apparent to convention observers that Wall Street had firmly opposed him until it was obvious that the public wanted him nominated. There were only obscure, unsubstantiated references to Wilson's anti-labor stance. Furthermore, although it was true that Wilson had been strongly conservative in his early political career, and had been helped into political office by those who thought he would stem the liberal tide then sweeping New Jersey, once in office, Wilson had led a progressive reform program. The best the Appeal could do was to attack Wilson personally, portraying him as a member of the upper class who would not and could not deal with workers (Cooley, 1973:38-39). Attacks on Wilson did not appear frequently in the Appeal after the Democratic edition of August 3, partially because he was difficult to criticize, but mostly because the Appeal knew its real enemy was the leader of the Progressive Party, Theodore Roosevelt. 
The Appeal's editors were quite worried about Roosevelt, and understandably so. They were hoping Taft would receive the Republican nomination and Roosevelt would stay out of the race. When Roosevelt broke from the Republican Party and made a direct appeal for the Progressive vote, the Appeal acknowledged the danger: "I am now convinced that our real danger lies in the direction (of Roosevelt). His candidacy will serve the purpose of stemming the tide towards Socialism. It will act as a buffer against the wave of radicalism that threatens the existing order" (July 20, 1912:1). There had been predictions of a Socialist vote of close to three million, but

This was before Roosevelt plunged into the arena. Before this campaign has proceeded far, a considerable number of these three million voters, conceded to the Socialists by our opponents, will be following the red bandana adopted as the emblem of the progressive party (Aug. 17, 1912:1).

Roosevelt was a great danger to the Socialists, and it is no surprise that the Appeal devoted much of their time to criticizing him. Discussing the soon to be revealed "Bull Moose" (Progressive) platform, the Appeal warns:

This will take the form of a document that will be as radical as words can make it.... It will voice the protests of an outraged people, vainly seeking relief.... Radical principles, hammered into the public mind by years of hard work by the Socialist press and Socialist speakers will be promulgated with such impudence and authority that they will be received in many quarters as original and their advocates hearlded as the saviors of mankind! (July 20, 1912:1).

It was bad enough that Roosevelt was stealing the Socialist's issues, but the Appeal honestly believed Roosevelt was insincere. They thought him a crude and clever politician, one who would ride the winds of change back into the White House. The above article continues, "Millions of men and women will fail to see the hidden purpose of all this, which is the building up of the political fortunes of an individual."
The Appeal tried to stave off the loss of votes to the Progressives by comparing them to the Bryan-Populist fusion campaign of 1896 which destroyed the Populist movement. The Appeal printed an article from the Philadelphia North American which said the function of the Progressive Party was to

propose measures which will make capitalism more secure against attack and discontent.... It will check the growth of Socialism. It will have the immediate effect of taking from the Socialist's strength that great body of followers who are not Socialists at all, but who joined the movement as a protest against the abuses which, at that time, they saw no way of remedying (Aug. 31, 1912:1).

An attempt was also made by the Appeal to contrast Socialist demands with those of the Progressives:

The Bull Moose convention declared for a minimum wage scale. Among the industrial demands of the Socialist Party is a minimum wage scale. The Bull Moose convention declared for votes for women, but denied Southern blacks a right to representation in their party. The Socialist convention declared for unrestricted and equal suffrage for men and women. The Bull Moose convention declared for reform of currency. The Socialist convention declared for the collective ownership and democratic management of the banking and currency system (Aug. 17, 1912:2). ${ }^{17}$

The Appeal was not so naive to think that there would be a total Socialist victory in 1912 , but they were willing to work toward that end. They felt that they had an excellent opportunity to gain inroads into American politics in 1912.

Here and now is our opportunity. Aggressive work today among the disappointed (of the major parties) means the laying of a sure and certain foundation for a sweeping victory in 1916 and it may come this year. Stranger things than a Socialst victory in 1912 have happened (June 29, 1912:1). 
However, the Appeal changed its tone after its editors realized, as the campaign intensified, that Socialists were losing their battle with Roosevelt. They admitted that,

the returns of the Vermont election justify what we have said about the effects of Roosevelt's campaign on the Socialist vote. Two years ago 1067 (votes), this year 1115 (votes). Vermont serves as an index of what we may expect.... We are going to win-yes-but we want to win now-not some day in the distant future (Sept. 14, 1912:1).

Roosevelt was more dangerous to the Appeal than any of the other candidates. Taft barely received mention because the Appeal knew it stood little chance of gaining votes among his followers. It attempted to discredit Wilson, but saved the most vicious and most personal criticism for Roosevelt. One article reminded its readers that Roosevelt had declared that he would not be a candidate for a third term. His campaign proved that he was "an unmitigated falsifier and totally destitute of principle or honor" (May 11, 1912:4).

Several articles advanced charges that Roosevelt wished to be a dictator. In support of the claims they cited the law that enabled the President to draft citizens between the ages of eighteen and fifty for military service. If one man came to office with the "proclivities of a dictator... it would be possible for him to summon all the able-bodied citizens of the country for war. It would give him a power greater than Ceasar" (October 19, 1912:1). ${ }^{18}$

The Appeal went so far to label Roosevelt a madman. It quoted Henry Watson, a veteran editor of the Louisville Courier Journal as saying, "I personally know that Roosevelt is of unsound mind. He carries all the marks typical of perverted understanding... The man is a maniac. Never can an act of his be defended" (Aug. 17, 1912:1). The only time the Appeal ceased excoriating Roosevelt was when he was shot and wounded during a campaign appearance. The right-wing worried that the socialism it espoused would be associated with the more militant left-wing, and the Appeal was quick to point out its non-violent philosophy:

The Appeal condemns the attempt to assasinate Theodore Roosevelt and we hope he will recover. The Appeal does not believe in assasination. Neither does any Socialist who understands the philosophy of socialism. There ought not to be a system that would prompt anyone to killing. The fact that reform of that system is sought in an effort to prolong its guilty life, is proof that it ought to be ended (Oct. 19, 1912:1).

The brutal tone with which the Appeal attacked Wilson and Roosevelt was quite understandable. Socialists had made gains in 1910 , mostly due to reform issues, and they expected 1912 to be even better. If Champ Clark and William Howard Taft had been the candidates, the right-wing socialist philosophy of trying to attract the discontented middle class might have been successful. But instead the Socialists faced two reform candidates who appealed to the same people that the socialists were courting. Their strategy was doomed to failure, and no amount of propaganda from the Appeal could stop it.

The Failure of the Socialist Party

Despite the threat from the Progressives, the Appeal to Reason maintained an optimistic tone as the 1912 election approached. In one issue the Appeal says, "Indications are that truly this is our year.... There is every reason to be encouraged. $\ldots$ This year we are actually going to enter upon the first fruits. of our efforts and begin to reap the victory" (Nov. 2, 1912:1). ${ }^{19}$ However none of the Appeal's predictions were accurate; Socialists did not elect a single United States representative or senator. Victor Berger, the lone Socialist congressman, lost his bid for re-election because of a Democratic-Republican coalition. The good news was that Debs polled 900,000 votes, almost six percent of the total vote, and the largest percentage ever by a Socialist candidate (Cooley, 1973:93). There were also scattered local victories that the Appeal pointed to as evidence of a growing Socialist movement. The election of 1,000 to 2,000 
local officials proved that the Socialist movement was alive, but had just become diffuse. The Appeal announced, "We are now in a position to do things. The next four years ought to see the leaven spread more rapidly than ever before, and gives us multiplied and substantial victories" (Nov. 23, 1912:1). But the Appeal made the same claim before the election. ${ }^{20}$

The reasons why the Socialist Party failed to gain ground in the crucial year of 1912 lie in the unique two party electoral system of the United States, and the constraints it places on third parties that attempt to enter the electoral system. The two party system exists and has its particular structure because of the nature of America's electoral rules. William Domhoff (1978: 129-130) explains:

It is the fact of presidential and gubernatorial elections, and the selection of legislators from single-member geographical districts which lead to the two-party system. The election of a single President for the nation, single governors for each state, separately elected senators for each state, and single representatives for each congressional district create a series of winner take all contests in which the most sensible strategy is to form the largest pre-electoral coalition even if numerous policy positions must be abandoned, compromised, or kept hidden from the voters.

The major parties are capable of a wide range of policy positions, which makes it difficult for the formation of issue oriented parties, because if their issues are popular enough, they are usually adopted by one of the major parties. ${ }^{21}$

The incorporation of many of their demands by a major party is exactly what the Appeal to Reason complained about, particularly when criticizing Roosevelt. Among the ideas incorporated by the Progressive Party which eventually became law were the adoption of the initiative, referendum, and recall. Other demands borrowed by the major parties included tougher inspection laws for workshops, factories and mines, the banning of child labor, and the establishment of minimum wage scales (Hofstadter, 1955). But big business was willing to accept some federal regulation; in fact, there was a basic consensus among political and business leaders as to what this regulation would be. Federal regulation during the Progressive Era was conservative in nature, because it preserved the existing power and economic relationships in society (Kolko, 1963:282).

In order for the right-wing Socialist strategy to have worked, the middle-class had to vote Socialist. This desire to attract middle class votes led to inconsistent editorial policies by the Appeal. It ran ten consecutive propaganda issues before the election in trying to appeal to different segments of the American population, but this resulted in contradictory declarations. ${ }^{2}$

Another way the Appeal attempted to attract middle-class votes was through blaming capitalism for all the problems in American society. An article states, "The crimes of theft and fraud will be wiped off the slate when it becomes possible for men to get what they want by honest rather than dishonest methods. Men, otherwise honest, will not be driven by hunger to set traps for the unwary" (Feb. 24, 1912:1). The Appeal also offered several stories about the horrors of capitalist greed. ${ }^{23}$ These stories criticized effectively the evils of capitalism, but these were the same evils being attacked by the Progressives.

The Appeal dealt with few concrete issues regarding the problems of capitalism, preferring instead to describe the utopia that would occur when socialism was fully introduced. ${ }^{24}$ This was one of the weaknesses of right-wing Socialist theory. Although the Appeal advocated establishing socialism gradually, there was very little explanation of the advantages of having a few Socialists in national office. The Appeal was consistent with right-wing theory when it discussed congressman Berger's importance in helping the strikers at Lawrence, Massachusetts, saying:

The advantages of a representative in Congress has been demonstrated beyond any question of doubt. Had there been no Socialist representative in Congress there would have been no congressional investigation.... It was Berger... who virtually compelled the president to demand an investigation and who 
introduced the bill and pushed it through Congress demanding an investigation of the working conditions at Lawrence (March 16, 1912:4)

But for the most part, the Appeal limited its position to vague claims about what a great nation America would be after the Socialists gained power, yet there was little evidence they would do so. The American voter was faced with a choice between a major party candidate, who would have the power to carry out policy, and a candidate who stood little chance of getting anything done until his party had won a majority of seats. Since this appeared to be only a hope in the distant future, they understandably voted for the major party candidate (Cooley, 1973:62-63).

A few specific reforms the Socialist Party proposed were not much more radical than those offered by the Progressives. Right-wing Socialist theory advocated appealing to the disaffected middle class, but in order to accomplish this the Socialists moderated many of their radical demands. Arthur Ekrich (1974:41) states, "During the period of the Progressive Era, the bulk of American Socialists moved in the conservative direction." Kipnis (1952:426-427) agrees saying:

In order to win votes from the middle class, right-wing Socialists repeatedly diluted their party's program until by 1912 it could be described as the left-wing of the Progressive movement. The state ceased to be an instrument of capitalist rule and became an impartial body which was gradually inaugurating a Socialist society.

Kipnis is supported by demands made in the Appeal: "The next step in the development of society is state capitalism... The politicians in Congress, obedient to the commands of their masters, (voters) will unload the railroads, telegraph and coal mines upon the government with a rush" (April 20, 1912:4). The government as an "impartial body" which would operate the utilities, railroads, and coal mines for the benefit of all sounds much like the philosophy of Theodore Roosevelt. In fact, he was probably the first major political leader to understand that what the public demanded was the absolute neutrality of the powerful state (Hofstadter, 1955:222-223).

This diluted brand of socialism did not appeal to the middle class, and it alienated the working class. The left-wing of the Socialist Party vigorously fought the abandonment of Socialist principles. Debs charged that party propaganda was being designed as bait for votes instead of as a means for educating the working class in principles of revolutionary socialism. In fact, many party members, once they had tasted political victory, bolted from the ranks of the party into the safer recluse of the Democratic Party (Lens, 1966:212). The left-wing felt that the party should seek only the votes of those who knew they were voting for revolutionary socialism. When the party had educated the workers in the principles of scientific socialism and organized them into industrial unions, they would then be ready to take power. Only then would a true Socialist society exist (Kipnis, 1952:300). ${ }^{25}$

For the left-wing the reforms the right-wing was asking for were too attenuated. If the major parties offered the same reforms, the worker would likely vote for a major party because it had the political power to instigate them. The biggest problem the Socialist Party had in 1912 was that it was in direct competition with the major parties without offering a substantially different program. In the introduction to Sombart's Why Is There No.Socialism In the United States?, C.T. Husbands (1976:XX-XXI) explains:

The more conservative major parties in America have frequently stolen the thunder from third parties by incorporating as their own parts of the platforms of these more reform oriented third parties. Of course this process has been made easier by the fact that any shift in a reforming direction impowed by circumstances upon the major parties has only had to be fairly marginal precisely because of the merely reformist character of the parties that have managed serious attempts to break into the two-party system during the most recent of American history. Thus the major parties have not been required 
to violate any fundamental ideological principles in the process of shifting their appeal to co-opt the support of threatening minor parties.

The Socialist Party failed to make progress after 1912 because it tried to operate in the American political system without offering a radical enough change. The party misread the growing Socialist vote of previous years as a growing Socialist sentiment, but as Kipnis (1952:34) stated, much of the vote was a call for reform. Encouraged by the increasing vote, the party dropped many of its more radical demands, which as Husbands (in Sombart, 1976:XX-XXI) argues made it easier for the major parties to stave off its threat. In some cases, the two major parties even combined to defeat Socialist candidates, as in Milwaukee, where Victor Berger actually had a higher percentage of the vote in 1912 than when he won in 1910, but was defeated by a Democratic-Republican coalition (Nov. 16, 1912:2). This can be seen as a sign of growing Socialist strength, but it also points out the fact that the two major parties were willing to cooperate in order to prevent a radical change of the system.

If the Socialists were to have had any chance starting a new major political party, they should have kept their more radical principles. By trying to attract the middle class the party alienated the working class. People must be strongly motivated to break from traditional political parties to the more unorthodox. Lens (1966:178-179) claims, "It takes more than a feeling of malaise, it takes a feeling of desperation." It. is apparent from the results of the 1912 election that the middle class did not have this feeling of desperation. They wanted reforms made, but they did not want radical change. The workers might have wanted radical change, but right-wing socialism did not offer it to them. Instead it offered a diluted brand of socialism, which was not much more radical than the major parties. Debs did poll 900,000 votes in 1912 , but by that time the main function of the Socialist Party was to get votes, not to change America from a capitalist to a socialist society.

\section{CONCLUSION}

The right-wing strategy of inaugurating socialism through the ballot meant that the Socialist Party had to attempt to appeal to all classes, not just the worker. Its aim was to capture the votes of the middle class who were unhappy with the programs of the major parties. To broaden its appeal, the Socialist Party moderated many of its demands until its program differed little in content from the reform parties (Kipnis, 1952:425). Rightwing strategy also forced the Socialist Party to compete within the unique electoral system of the United States. The party system of politics is designed to attract as diverse a group of ideas as possible, and when the Socialist Party weakened its demands it made it easier for the major parties to absorb them. The liberal policies of the party caused it to lose much of its appeal to the working class because the reforms it called for were not much better than those of the major parties that were quite willing to incorporate some Socialist demands in order to stave off its threat. In addition, the major parties offered immediate action, which gave the worker plenty of incentive to vote for them.

The Socialist Party failed to recognize that in order to have major electoral success, it had to offer a distinct alternative. It might have been more successful if it had kept more radical demands and tried to establish itself as the worker's party. If the Socialist Party could have effectively organized the workers, it might have been able to establish itself in the American electoral system. But with the right-wing in firm control of the party, it instead offered a diluted brand of socialism which appealed to neither the working or middle class. By 1912, the Socialist Party was more interested in obtaining votes than in changing American society. It was fooled by its earlier electoral success, and sold its soul to attain more. The Socialist Party contributed to the passage of some reform legislation, but forgot its main goal, bringing about a Socialist society in Ameri- 


\section{FOOTNOTES}

1. For example see Failure of a Dream (eds. John Laslett and Seymour Lipset, Garden City: Doubleday, 1974); Albert Fried, Socialism in America (Garden City: Doubleday, 1970); James Weinstein, The Decline of Socialism in America (New York: Monthly Review Press, 1967); Daniel Bell, The End of Ideology: On the Exhaustion of Political Ideas in the Fifties (Glencoe: Free Press, 1960); Bernard Johnpoll, Pacifists Progress: Norman Thomas and the Decline of American Socialism (Chicago: Quadrangle Books, 1970); David Shannon, The Socialist Party of America, a History (New York: Macmillan, 1955); Ralf Dahrendorf, Class and Class Conflict in Industrial Society (Stanford: Stanford University Press, 1959); John Laslett, Labor and Left: A Study of Socialist and Radical Influences in the American Labor Movement (New York: Basic Books, 1970); Gabriel Kolko, The Triumph of Conservatism (New York: Free Press, 1963); Richard Hofstadter, The Age of Reform (New York: Alfred A. Knopf, Inc., 1955); Ira Kipnis, The American Socialist Movement (New York: University Press, 1952).

2. The method of study was a content analysis of the The Appeal to Reason for the year 1912. Both the Appeal and the Socialist Party reached their peak that year. Furthermore, 1912 was a presidential election year. The election coverage of the Appeal offered rich information about party strategy at a very critical juncture.

3. The major Populists in the Socialist Party had been dissidents in the old agrarian movement (Green, 1978:13). Green's (1978:24) study of socialism in the Southwest reveals that "from the very start, the southwestern Socialist Party showed a greater continuity with the People's Party in leadership rather than in membership." The very active and more radical members of the Populist Party were more likely to join the Socialist movement.

One reason for the lack of continuity between the Populist and Socialist Party was that farming was becoming more prosperous. After 1897 , new international supplies of gold brought an inflationary movement which the farmers had desired. The general prices of crops rose as wheat went from 72 cents a bushel in 1896 to 98 cents in 1909 ; corn from 21 cents to 57 cents; and cotton from six cents to 14 cents a pound (Hofstadter, 1955:110). The new prosperous farmers probably joined the Democratic Party. The newly instated poll tax kept many of the poorer farmers from voting at all. Population shifts from southern farms to northern cities also altered the locations of voting strength for the Socialist Party (Green, 1978:26-27).
4. Born in Indiana in 1854 , Wayland made a small fortune as an editor and a publisher. In the 1880 s Wayland moved to Colorado and started editing a Populist-labor paper. He was converted to socialism in 1890 by William Bradfield, an English born cobbler, who supplied Wayland with some Socialist literature. Wayland participated in the Populist campaign of 1892 and then returned to Indiana and started publishing a new weekly called the Coming Nation, a combination of utopian socialism and radical populism which eventually reached a circulation of over fifty thousand (Cooley, 1973:4; Green, 1978:17-18).

Wayland attempted to escape the capitalist world in 1893 by organizing a cooperative commune according to Socialist principles. He struggled for two years to make a success of this utopia, but the venture eventually failed because of internal bickering (Cooley, 1973:4-5). After Wayland's grand experiment failed, the Coming Nation suspended publication, and Wayland moved to Kansas City, Missouri, and started the Appeal to Reason.

5. Girard was an ideal location because the farmers and miners of the region were "disaffected from populism and ripe for socialism, and Wayland attracted a good number of southwestern readers by launching an all out attack on Bryan's fusion and free silver campaign" (Green, 1978:18).

6. Although the Appeal had a newspaper format, it was not really a newspaper, but rather a Socialist propaganda pamphlet. According to Cooley (1973:2) the Appeal "did not serve a geographical area, but an ideological community that was national in scope. It did not present an objective account of events, but an interpretation of economic and political trends from a Socialist viewpoint. It did not seek to inform, but to convince and convert. It was a part of a national Socialist movement that sought ... to bring about a Socialist America." The readers of the Appeal were not all farmers. It was also popular in the fisheries of the West, the mining camps of the Rockies, and the factories and railroad yards of the East (Clement and Symes, 1934:226-227).

7. Although the Appeal was quite valuable to the Socialist Party, many of the other Socialist publications criticized it. The basis for this criticism came from Wayland's business methods. His promotional abilities allowed the Appeal to actually make a profit while other Socialist newspapers struggled on the brink of failure. The "Appeal Army" competed for such prizes as trips to Europe, motorcycles, bonuses and commissions for selling subscriptions (Cooley, 1973:7). Socialist newspapers attacked the Appeal for its capitalistic business methods, its employment of salesmen who may not have been true 
Mid-American Review of Sociology

Socialists, and its reformist approach to socialism. Part of these critSocialists, and its reformist approach to were also true (Kipnis, 1952: icisms stemmed from jealousy, but many were also true (Kipnis, 1952: 250). Wayland did make money from the Appeal, but he invested much of that money back into the paper itself. Between 1900 and 1912 much of that money into better quarters five times, and Wayland always the paper moved into better quarters five tiles, 1973:10). An article bought the best equipment available (Cooley, 1973:10). An article in the Appeal stated: "The labor commissioner of Kansas reports the Appeal office as the best plant in Kansas for ventilation, for short hours, rate of wages, and protected machinery. Employees work fortyseven hours per week. No one under eighteen years of age will be employed.... From sixty to ninety people are employed on the Appeal (Jan. 27, 1912:3).

8. An article in a 1912 edition of the Appeal states the editor's opinions on the matter:

The work of this paper is to make Socialists. With a singleness of purpose that has at times been greatly mising understood, the Appeal has steadfastly kept on its way in its chosen field. In mapping out our work, the Appeal has never lost sight of the fact that there are in this country $15,000,000$ voters who do not support the country 15,000,00 voters who do not support the Socialist ticket. To make converts of a majority of these voters is the mission of the Appeal, and it has no other. On diverse occasions in the past, attempts have been on to Appeal into party controversies, but it made to drag the $A$ ppeal into party controversies, but it has refused to become partisan to any of these affairs. .. Once committed to a position on party tactics, it is inevitable that we must fight it out on that line right or And on appeal, wrong. And on party affairs an right (Aug. 3, 1912:4)

9. In their history of radical politics in the United States, Lillian Symes and Travers Clement (1934:265-266) argue:

Between 1910 and 1917 there were probably few intelligent A to some form of who did not profess to some form a social, economic, or artistic heterodoxy. To be a socialis syndicalist, anarchist or at the very least a left-wing libera was merely to be in tune with the pre-war sociological in was me res in the finitive.... The wave of insurgency reached it cria year in which Roosevelt ran on a program of Social Righteousness, Wilson unfurled the banner of New Freedom, Debs polled 900,000 votes without the benefit of woman suffrage and Emma Goldman became one of the most popular lecturers in America.
The Appeal to Reason

10. This success included the election of a United States congressman (Victor Berger), one state senator, sixteen state representatives, twentyeight mayors and various other city officials (Cooley, 1973:20-21). But according to Kipnis (1952:347):

Few local victories were won on the issue of capitalism versus socialism. In fact, this issue was usually kept well in the background. The great majority of Socialists elected to office between 1910 and 1912 were ministers and professional men who conducted their successful campaign on reform questions that appeared crucial in their own communities. In California, for example, not one successful Socialist campaign could be described as anything more than a contest between reformers and old line party bosses.

11. The Reform movement basically reflected the sentiments of the new middle class which had arisen recently in the United States. The industrial revolution had rearranged American society and the reformists "sprang from the new middle class of urban society, their numbers including many of the established leaders who had been replaced by the new industrial elite" (Mazmanian, 1974:54). The new middle class of small businessmen, technicians, salaried professionals, clerical workers, sales people and public service personnel arose along with the great corporations. This was by far the most rapidly growing class in the population and they formed a large and significant political group (Hofstadter, 1955:215).

The middle class was losing economic power in the new industrial society. They were a large part of the new "comsumer" society and the general price rise starting in 1897 contribued significantly to Progressive discontents. This price rise took on added significance because the Progressives associated it with two other trends: the development of an organized labor movement, and the tremendous increase in the number of trusts in American industry. The middle class citizen saw himself as a member of a vast but unorganized and therefore helpless consuming public. The Progressive movement can be viewed as a middle class revolt against industrial discipline: a revolt of the unorganized against the forces of organization (Hofstadter, 1955:168-170, 214).

12. The Progressives were basically conservative. Despite their radical rhetoric they never strayed from middle-of-the-road politics. Approximately two-thirds of the members of the Progressive Party were successful businessmen and lawyers, and few workers or farmers could be found in important party positions. On the average, party members were urban, upper-middle class, Anglo-Saxon, Protestant refugees 
from the Republican Party. Some members were bitterly anti-labor, and most wanted a clean, efficient government compatible with their class interests. Above all, "the reform sentiments were flexible within the larger bounds of capitalism" (Kolko, 1963:195-196). Hofstadter $(1955: 250)$ states:

It is impossible not to conclude that despite the widespread public agitation over the matter, the men who took a conservative view of the needs of the hour never lost control. Roosevelt was typical of the Progressives. His real impulses were deeply conservative and he would not have been a Progressive at all if it wasn't necessary to combat more radical thought of his day.

13. One Progressive said that the rise of the Reform movement was the result of: "'an intuitive perception that, somewhere, something is wrong-that in the face of the future there is a disturbing, even sinister look.' "The nation was at a crossroads leading on one side to corporate paternalism and on the other to state socialism-both fatal to individual liberties. Fortunately there was another path that could still be taken: individual opportunity-the opportunity, actual as well as in theory, to each individual to participate in the proprietorship of the country" (Hofstadter, 1955:221-222).

Wilson's speeches expressed the middle class belief that the economic order was not so much a structure organized for the production and distribution of goods as a system intended to stimulate and reward certain character traits of the individual. Wilson appealed to those who had been raised on the old ideal of opportunity and the notion that success was a reward for energy, efficiency, frugality, and perserverance. People thought they should compete in the exercise of these qualities and be rewarded for them. They thought of life as a "race." Wilson pointed out that this "race" was no longer being run, because of the rise of monopolies within American industry; a situation he vowed to change (Hofstadter, 1955:221-223).

14. In one speech Wilson said that he was engaged in a crusade against powers that have governed us-that have limited our developmentthat have determined our lives-that have set us in a straightjacket to do as they please.... This is a second struggle for emancipation. If America is not to have free enterprise then she can have no freedom whatsoever" (Hofstadter, 1955:226).

15. Other criticisms stated: "Wilson's active life has been spent as a teacher and a president in a college attended by families of the upper class"
(Aug. 3, 1912:1). "Wilson lives in an atmosphere completely apart from the terrible struggle for bread. The working class fits into his scheme nowhere except as the burden bearers for the more fortunate members of society" (July 13, 1912:1).

16. The Appeal called Wilson a nominee of Wall Street because of the political maneuverings during his nomination. Wilson's nomination was not secured until the forty-seventh ballot when the head of the New York delegation, Charles Murphy, the Tammany boss and a disreputable politician, switched New York's votes to Wilson because he realized Wilson was near victory and he desired to reap the political rewards from putting Wilson over the top. The Appeal called Wilson "the nominee of Wall Street... he could never have received the necessary two-thirds vote of the delegates without Wall Street... (it) gave him the nomination" (Aug. 3, 192:4).

17. The Appeal also used cartoons to criticize Roosevelt. They were quite vivid and communicated their point successfully. On August 17, 1912, the front page showed a large cartoon of a leopard with Roosevelt's face. The leopard's spots were labeled "Alton Steal," "Enemy of Labor," and so on. The caption read "Can the leopard change his spots?" The cartoon was the largest ever published in the Appeal, being five columns wide and extending three-quarters of the page. The Appeal predicted that this cartoon would "make history" and attempted to use it as an anti-Roosevelt poster wherever he was scheduled to appear (Cooley, 1973:48). Although this cartoon conveyed its point, it was not any more significant than any other effective editorial cartoon.

A cartoon was also used by the Appeal to represent Roosevelt's radical rhetoric, tricking the worker into voting for him. The cartoon depicted Roosevelt walking towards a man labeled "Labor" and saying, "I'm Moses sent to save you from socialism." However, behind his back Roosevelt carried a huge stick labeled "capitalism." The caption read "Speak softly and carry a big stick" (Oct. 19, 1912:1).

18. Sensationalism was another technique adjoined to the charge that Roosevelt wished to be a dictator: "No force save the Socialist Party and the Appeal Army can prevent this strange freak from being elected president of the United States and ultimately reaching his goal-a dictatorship that will make Diaz look like a model democrat. The Appeal has in its possession information touching Roosevelt's plans that would make the nation gasp. We do not care to make this information public, for the very good reason that no one would believe it" (Aug. 3, 1912:1). 
It is highly unlikely that the Appeal had such information. "Making the nation gasp" is exactly what the Appeal wanted to do, and it would not have hesitated from revealing such information.

19. The editors predicted (Nov. 2, 1912) that the Socialists would elect at least one United States representative in New York, Wisconsin, California, Oklahoma, Pennsylvania, Nevada, Kansas, North Dakota, Ohio, and Minnesota. In addition, Minneapolis, Minnesota would elect a Socialist mayor, and Nevada would elect a United States senator while also casting its three electoral votes for the Socialist presidential candidate, Eugene Debs.

20 The Socialist Party has never again been as successful as they were in 1912. Debs did receive more votes in 1920 , but his percentage of the vote was lower. By 1921, membership in the Socialist Party had dropped to 13,500 , and for all practical purposes it was dead. The final deterioration of the Socialist Party was caused primarily by international events. The Bolshevik Revolution caused the Red Scare of 1919 when many people thought the United States was being overrun by communists. There was a backlash against radical forces in the United States which deterred people from joining the Socialist Party. The first World War caused division within the ranks of the party between members who thought the United States should maintain an isolationalist position, and others who thought that patriotism was their main duty. Many of the groups associated with the Socialist International gave support to the war, which was supposedly against Socialist principles. This further weakened support for socialism in America. The formal expulsion of the left-wing from the party in 1919 also cut down membership (Kipnis, 1952:420). However, this decline started in 1912, when the Socialist Party failed to gain ground in the election during a time when Americans seemed open to progressive ideology.

21. In fact, the main role of third parties in the United States has been "not to win or govern, but to agitate, educate, generate new ideas, and supply the dynamic element in our political life" (Hofstadter, 1955:97). The major parties attempt to form a large enough coalition of diverse political interests to get into power, and once in power to remain there. When a third party's demands become popular enough, they are absorbed by one or both of the major parties, and the third party loses it strength (Hofstadter, 1955:97).

22. For example one issue says, "There can be no absolute private title to land. All private titles must be subordinate to the public title. The
Socialist Party demands the collective possession, control, and management of all land" (Jan. 27, 1912:1). But when the Appeal attempted to attract the farmers into the Socialist fold it said that the party had no intention of taking away the private land actually used by the farmers (Sept. 21, 1912:1)

23. One article tells the story of Leona Fugate, an eight year old girl, who was run over by a streetcar operated by the Metropolitan Street Railway Company, a Standard Oil interest. The Appeal noted that the engineer operating the car was a nonunion man and that the streetcar company refused to pay any compensation to the young girl's family to help pay the medical bills. Leona's father was a union man who had been out of work and the best that could be done for her was the purchase of a small baby carriage for her to be pushed around in (April 27, 1912:1).

24. The pages of the Appeal were full of articles proclaiming the virtures of the Socialist state which would soon arise

What a great and healthy society will it be, where every member shall contribute his logical share of work. No more money, and accordingly, no more speculation, no more theft, no more dishonorable dealing, no more crimes incited by the craving for wealth. No young girls will be married for their dowry, nor old relatives assassinated for their heritage, no passers-by would be murdered for their purse. No more hostile classes of employer and employed, of workingman and capitalists, and accordingly, no more laws and courts and armed forces to guard the unjust accumulations of one class against the hunger of the other. No more idlers of any kind, and therefore, no more property owners nourished by their rent, no more people living idly in their incomes granted by chance, in one word, no more luxury and no more misery! Thanks to the many new hands employed in labor, thanks above all to the machines we will not have to work more than four, perhaps but three hours a day; and oh how much time there will be for enjoying life! For it will not be a barrack, but a city full of freedom and gaiety, where everyone remains free to choose his pleasures with enough time to satisfy his just desires, the joy of loving, of being strong, being beautiful, being intelligent, and taking his share from inexhaustible nature (April, 20,1912:2).

25. Sidney Lens (1966:212) in his history of radicalism in America does give the right-wing some credit. He feels that the decision of the Socialist Party to work for immediate and realizable reforms resulted in 
some success. The worker could not be expected to accept the great Socialist society all at once, but rather had to go through unionism and strikes before being convinced that there was a link between the struggle for higher wages and the ultimate demand for the abolition of the wage system. The picture had to be shown in pieces rather than all at once. However, this resulted in dilution of the Socialist program. Allegedly, the worker needed to receive more wages, more leisure and more security in order to be prepared for revolutionary consciousness. But history disputes this strategy because affluence of the worker has generally made them less revolutionary (Husbands in [Sombart, 1976: $\mathrm{XXI}]$ ).

\section{REFERENCES}

Appeal to Reason

1912 (January 27), (February 3), (March 16), (April 20), (April 27), (May 11), (June 29), (July 13), (July 20), (August 3), (August 17), (August 31), (September 7), (September 14), (September 21), (October 19), (November 2), (November 16), Chandler, A.D.

(November 23). Girard, Kansas.

1977 The Visible Hand: The Managerial Revolution in American Business. Cambridge: Harvard University Press.

Clement, R. and Symes L.

1934 Rebel America. New York: DeCapo Press, Inc.

Cooley, R.L.

1973 The Appeal to Reason and the Presidential Campaign of 1912 Unpublished M.A. Thesis, University of Kansas.

Domhoff, W.G.

1978 The Powers That Be: Processes of Ruling Class Domination in America. New York: Vintage Books.

Durden, R.F.

1963 "The Cowbird Grounded: The Populist Nomination of Bryan and Watson in 1896." Mississippi Valley Historical Review 12 (December):397-423.

Ekrich, A.A.

1974 Progressivism in America: A Study of the Era From Theodore Roosevelt to Woodrow Wilson. New York: New View Points.

Goodwyn, L.

1976 Democratic Promise: The Populist Movement in America. New York: Oxford University Press.

Green, J.R.

1978 Grass Roots Socialism. Baton Rouge: Louisiana State University Press.
Hicks, J.D.

1931 The Populist Revolt, A History of the Farmer's Alliance and the Hofstadter, R

People's Party. Minneapolis: University of Minnesota Press.

1955 The Age of Reform. New York: Alfred A. Knopf.

Kipnis, I.

1952 The American Socialist Movement. New York: University Press. Kolko, G

1963 The Triumph of Conservatism. New York: The Free Press.

Lens, S.

1966 Radicalism in America. New York: Thomas Crowell Company. Mazmanian, D.

1974 Third Parties in Presidential Elections. Washington, D.C.: The Miller, R.C. Brookings Institution.

1925 "The Background of Populism in Kansas." Mississippi Valley Sombart, W.

(1906) Why Is There No Socialism In the United States? London:

1976 Macmillan Press. 